чистоты повышает их биологическую активность. Поскольку типичные коллоидные наночастицы серебра имеют размеры 25 нм, а отечественные менее 10 нм, то их применение, по предварительным данным, позволило в 30 раз снизить концентрацию в коллоиде основного вещества при том же положительном эффекте бактериоцидности.

В первой группе животных после моделирования асептической раны гистологически при спонтанно протекающем заживлении на 1-е сутки эксперимента наблюдалась обширная зона некротизированной клетчатки и прилежащих мышечных волокон инфильтрированных лейкоцитами и вне сосудистыми эритроцитами, ткани в состоянии выраженного интерстициального отека. Общая площадь интерстиция после моделирования асептической раны в 2,7 раза превышает показатель нормы.

Во второй и третьей группах животных после моделирования асептической раны и применения лимфостимулирующего коктейля на 1-е сутки эксперимента также наблюдалась зона некротизированной клетчатки инфильтрированной лейкоцитами и вне сосудистыми эритроцитами, но интерстициальный отек превышает показатель нормы только в 1,9 и 1,8 раза соответственно.

В четвертой группе животных на 1-е сутки морфометрически общая площадь интерстиция после моделирования асептической раны и применения наноструктур с наночастицами серебра на фоне лимфостимулирующего коктейля только в 1,3 раза превышает показатель нормы. На 7-е сутки эксперимента при использовании лимфостимулирующего коктейля с наночастицами серебра наблюдается раннее восстановление и нормализация структуры, еe стромального компонента и сосудистой сети. Это приводит к выраженному снижению отечных явлений, уменьшению количества клеточных элементов, что свидетельствует об ускорении регенерации и восстановлении полноценной структуры региона хирургической травмы.

Выводы. Показано положительное влияние комплекса перекиси водорода с наночастицами серебра в сочетании с хитозаном на ускорение заживления обширной асептической хирургической раны.

\section{СПИСОК ЛИТЕРАТУРЫ}

1. Автандилов Г.Г. Основы количественной патологической анатомии: Учебное пособие для слушателей последипломного образования /Г.Г.Автандилов.-М.: Медицина, 2002.- 238 с.

2. Акрамов Э.Х., Габитов В.Х. и соавт. Избранные вопросы гнойной хирургии: Руководство для врачей.- Бишкек - Новосибирск, 1999.- 540 с.

3. Бородин Ю.И. Регионарный лимфатический дренаж и лимфодетоксикация // Морфология, 2005.- т.128.- № 4.- С.25-28.

4. Букина Ю.А., Сергеева Е.А. Антибактериальные свойства и механизм бактерицидного действия наночастиц и ионов серебра // Вестник Казанского технологического ун-та. 2012. № 14.- С.170-172.

5. Габитов В.Х., Песин Я.М. Способ лифостимуляции при инсультах спинного мозга. Киргизпатент № 21, 1999.

6. Гостищев В.К., Омельяновский В.В. Пути и возможности профилактики инфекционных осложнений в хирургии // Хирургия. 2012. №8. С.511.

7. Камская В.Е. Хитозан: структура, свойства и использование // Научное обозрение. Биологические науки. - 2016. - № 6. - С. 36-42.

8. Коненков В. И. Лимфология / В. И., Коненков, Ю. И. Бородин, М. С. Любарский Новосибирск. - 2012. -1103 с.

9. Савельев В.С. , Кириенко А.И. Клиническая хирургия / под ред. В.С. Савельева, А.И. Кириенко // национальное рук.: в 3 т..- М.: ГЭОТАР - Медиа, 2009.-T.2.

\title{
PUBLIC HEALTH OF UNITED TERRITORIAL COMMUNITIES IN UKRAINE
}

\author{
Hrytsko Roman \\ Candidate of Medical Sciences, \\ Doctor of Sciences (State administration), \\ Associate Professor at the Department of Infectious Diseases of \\ Danylo Halytsky Lviv National Medical University. \\ Lviv, Ukraine \\ DOI: $\underline{\text { 10.31618/ESU.2413-9335.2019.2.64.222 }}$
}

\section{ANNOTATION}

The article highlights basic principles of state and public administration of individual health care and public health care of united territorial communities, which are the basis for public community in Ukraine.

Key words: united territorial communities, public health, integrative family medicine, state and public administration of public health, record of public health.

The Constitution of Ukraine defines that management of rural health care establishments is performed by territorial communities of villages and urban villages directly via created local government authorities. In the system of local administration, territorial community is the primary element of villages, urban villages and towns, which has the rights to solve problems at local level within the Constitution and laws of Ukraine. These rights include elaboration of the programs of social and cultural development, 
target programs of regulation of public relations in public health care [1].

Special attention is paid to public health care, measures regarding prevention of diseases, improvement of public health and prolonging the duration of individuals' productive life [2].

An important role of local government authorities is stated in the Decree of the President of Ukraine "On conception of the development of public health care in Ukraine" [3] dated 07.02.2000 № 1313. It emphasizes that territorial community provides a control over services and financial issues of public health care, and its major part should be provided at the level of primary medical care based on family medicine.

Family medicine in Ukraine is based on prophylactic measures of specialists' work. It integrates the notions of family medicine in clinics - family territorial community - family doctor and involves specialist physicians to improve the condition of public health in residents of family territorial communities.

Community is a collection of individuals, united due to certain conditions or circumstances. Most commonly, such condition is the geographical territory where certain population lives: village, urban village, town, as well as family territorial community. Communities can also be defined by other criteria: common workplace, profession, common culture, religious denomination etc.

Public health is the condition of demographic structure, physical and intellectual potential, moral and psychological climate, which provides certain level of life in the community and performance of other social functions within historical period of time [4].

Public health involves all aspects associated with health of each individual of the community (resident), but it is not limited to only characteristics of individual health of community members.

Most frequently, definition of health is presented in preliminary statement of the statute of World Health Organization (WHO). In this definition, social (public) criterion is considered along with such traditional criteria as physical (somatic) and mental (psychic). Inseparability of biological and social aspects in human nature makes such approach to health care of the individuals justified.

Physical and social wellbeing of an individual provides capability to fulfill the following vital functions, as ability to perform physical work (mobility, working ability), cognitive activity (perception, remembering and interpreting information, adequate emotional evaluation of events in the environment and one's place in it, reproduction and birth of healthy offspring, as well as ability to differentiate between notions "self-not self" based on cell-mediated and humoral immunities. It allows to state that the definition of public health is referred to somatic, mental, immunological and reproductive health of each individual.

With the adaptation of the Law of Ukraine "On deliberate union of territorial communities" dated 05.02.2015, a new stage of decentralization, reforms of local government as well as administrative and territorial reforms started in Ukraine. Amendments were also made to budget and tax laws aimed at providing united territorial communities with financial independence via adoption of respective rights, revenues and expenses. They were taken into account for determination of inter-budget relationship with state budget by providing direct state donations and subventions [5].

Similar to districts, united territorial communities received and became holders of medical subvention for primary medical care directly from state budget. Amount of this medical subvention, as for a district, is calculated according to a certain formula depending on the number of the population.

Distribution of budget for health care between district budget and budget of united territorial communities required organizational and structural division of health care system, which provided medical care for individuals of corresponding residential areas.

According to the Law of Ukraine "On amendments to Fundamentals of legislation of Ukraine on health care regarding improvement of providing medical care” dated 07.07.2011, № 3611-VI, a family doctor, who provides primary medical care for united territorial community and is a public doctor, has the right to coordinate and integrate professional activities of any specialist in health care system of the country in order to deal with the problems of a patient and public health of territorial community [6].

Municipal city polyclinic №5 in Lviv (Ukraine), acting as a clinic of integrative family medicine, ranks high in modernization of family medicine development at regional level. In this complex and comprehensive process, a leading role belongs to the center of primary medical care, where 80 family doctors and 94 nurses work in 59 family territorial communities. Along with family medicine, specialist physicians also provide medical care in the same establishment. They work in a consulting therapeutic and diagnostic center and are focused on formation, maintenance and improvement of wellbeing of each healthy individual and health recovery of patients in one of the administrative districts of Lviv city. Doctors in the aforementioned establishment of health care improve public health of the residents within territorial community of one district in Lviv.

Specialists of integrative family medicine clinic, working in family territorial communities, actively involve state and local authorities, professionals of specialized and highly specialized medical care in the formation, maintenance and improvement of wellbeing of healthy residents of various age groups and recovery of health of ill individuals in united territorial communities.

Integrating efforts, united territorial community, via certain individuals and public organizations, participates not only in improving health of its residents and in forming high level of public health, but also draws a public scheme of health care, which is an important component of public health care that is being developed in Ukraine.

Thus, the tasks of creation of effective public health care system of united territorial communities are the following: 
1. Provision of sole process of early diagnosis, primary prophylaxis of diseases or reconstructive therapy, medical and social rehabilitation of patients and disabled persons with high quality and efficacy in different diseases and traumas;

2. Formation, maintenance and improvement of individual wellness of healthy individuals of various age groups and public health of territorial communities based on the principles of medical valeology and sanology;

3. Creation of conditions for harmonious combination of professional interests of integrative medical care using human and technological resources of state system of public health care and united territorial communities;

4. Improvement of possibility for organization of effective medical $* * *$ in equal health problems both of individual members of territorial community and of public health based on the principles of economy of all resources in the system of health care and patients.

5. Creation of conditions for reducing elective apparatus of administration of primary medical care, which is becoming mobile, cheaper and more effective regarding public health of territorial community;

6. Provision of optimal form of combining interests of territorial and local administration in the system of state and public regulation of public health care based on integrative family medicine in the sole territorial medical space;

7. Development of external relations with international structures, which provide medical care in different countries based on public health care, extending possibilities regarding public health care;

8. Improvement of scientific and practical level of continuous professional development of specialists in family medicine regarding formation, maintenance, strengthening and recovery of both individual health and public health of united territorial communities.

The process of management of public health in united territorial communities is based on the record of residents' health, compiled by family doctors, who provide primary medical care within family territorial communities [7].

Based on monitoring of the record of public health of united territorial community, specialists in family medicine elaborate individual plans for rehabilitation of certain persons and perspectives for improvement of wellbeing of healthy individuals and recovery of health of ill individuals, which has a significant influence on improvement of health condition within territorial communities.

All these processes are implemented based on complex mechanism of state and public administration of health care improvement within united territorial communities of Ukraine.

\section{References}

1. To R.Yu. Hrytsko's article "Public health of united territorial communities in Ukraine"

2. The Constitution of Ukraine. - K.: Prosvita, 1996. $-80 \mathrm{p}$.

3. Clinic of integrative family medicine / Edited by Borys Lemishko, Yevhenia Zaremba, Andrij Bazylevych. - Lviv: Spolom, 335 p.

4. On conception of health care development of the population of Ukraine / The Decree of the President of Ukraine dated 20.06.2000, № 989 // Medychnyi visnyk Ukrainy. - 200. - № 25. - P.3

5. Public health and public nursing. Edited by Prof. Ye.Ya. Sklyarov, M.B.Shehedyn, B.B. Lemishko. - K.:Medicine, 2008, 223 p.

6. On deliberate union of territorial communities / The Law of Ukraine dated 05.02.2015, № 157-VIII.

7. On amendments to Fundamentals of legislation of Ukraine "On health care regarding improvement of providing medical care" / The Law of Ukraine dated 07.07.2011, № 3611-VI.

8. Hrytsko R.Yu. State administration of education system of family medicine specialists in Ukraine / R.Yu. Hrytsko. - Drohobych: Posvit, 2014. 363 p. - P. 95-101. 